\title{
The Image Of The Social Spirit In The Images Of Togay Murod's Novel "You Can't Die In This World"
}

\section{Zavqiddin Suvonov \\ Tashkent State University Of Uzbek Language And Literature Named After Alisher Navoi, Uzbekistan}

Journal Website: http://usajournalshub.c om/index,php/tajssei

Copyright: Original content from this work may be used under the terms of the creative commons attributes 4.0 licence.

\section{ABSTRACT}

Fiction explores life in two ways: one for approval and one for rejection. Accordingly, literary critics divide images into the following types, but this approach is also relative.

\section{KEYWORDS}

Fiction explore, rejection, literary critics, images into the following types.

\section{INTRODUCTION}

1. He is a positive image if he combines mainly positive qualities with his worldview, behavior, character traits and can be an example for the reader, leading the people to goodness and perfection. "In literature and art, images are created that are, in essence, positive images. However, if they are considered as a positive image, they are not enough to set an example for others, and in many respects they cannot be at the level of an ideal image." This will depend on the creative skill.

2. Behavior, by its very nature, carries mainly negative qualities, is able to arouse the student's hatred for himself, leads society to decline, and is a negative image. "The 
fate of a work is determined by whether all the images, all the scenes, all the phrases correspond to the meaning chosen by the writer, and whether they serve to fully reveal the meaning." If the writer expresses a mood that is contrary to the chosen meaning and provokes dissatisfaction in the reader, it is a negative image.

If we think about the system of images in the play, one aspect of the issue should be emphasized. The point is that the meaning that the creator wants to convey through the work is first and foremost concentrated in the images. In this, the question of the protagonist is especially important. The clear meaning in the main image does not allow the introduction of materials that are not related to the meaning in the logic. There are many works in Uzbek literature that correspond to this idea.

\section{THE MAIN FINDINGS AND RESULTS}

Togay Murad's novel You can't Die in This World, like the other works of the artist, has aroused good public opinion, and in a sense serves as a source for revealing the diversity of his work. Because the protagonists of the work give the impression that they are walking in the midst of spiritual storms, in the midst of emotional flames. The novel was translated into French and published by Les Editions DU NET in Paris. Unprecedented works of art live forever. They are not the property of one nation or people, but the property of all mankind.

The play depicts the wounds of the famine of the thirties of the twentieth century, as well as the suffering of ordinary people and their past. The play emphasizes social life and psychological description. The author describes it as someone who sees the trade and social process that befell the people during the Soviet era.

If we look at the statistics of the images in the play, they number 43 . There are 44 people with the image of the author (if allowed). Qodir Qul, Holmat Malay, Eson Hizmatkor, Botir Qoshchi, Botir Qoshchin's Wife, Guard, Farmers, Mother, Child, Mirzakhojaboy, Zainab, Obod, Commander, Ashir Momo, Chori Bobo, NVKD, Employees, Dilbar, Yuldash Akhunboboev, Khrushchev, Brezhnev, Sharof Rashidov, Rajabov, Madiev, Turakulov, Turakulov's son, Mirzaev, Klara, religiousmentally ill, historian mentally ill, rich patients, victims of military rule, inventors, inventors, director, deputy director, head of laboratory, lawyers, Grigorenko, Suslov, Hanifa Rajabovna, blacksmith, stonemason, driver. The work consists of 74 chapters.

Some literary critics say that Togay Murad and his protagonist, Botir, have some similarities in their mentality. Because the writer revived the historical process on the example of an Uzbek official. His protagonist sometimes sympathizes with the victims of the famine, sometimes with the achievements of Soviet medicine, and sometimes with irony to the speeches of religious figures.

The reader is faced with the problem of a deeper understanding of the writer's work. The idea of a work of art requires an approach from the writer's point of view, with an understanding of his spiritual and social worldview. Heroes need to know the concept of creativity in order to have a deeper understanding of the logic of the character. In understanding this situation, it is necessary to take into account such factors as the historical conditions in which the image moves, the socio-political situation in which the writer 
lived, the ideological environment, the literary process, the writer's style.

The sharp eyes, deep creative observation and kindness of a true writer, who knew the life of the city and the life of the people from the inside, and who was able to infuse the hearts of those suffering people with sincere sympathy for them, in the interpretation of every detail and image of the heroes, speech and inner thoughts. intentions are noticeable. The novel makes us think in these aspects as well.

After all, talent alone, or good intentions and skill alone, are not enough to create a true artistic creation. For him, inner feeling and rage should be enough. Togay Murad himself says: "So, the power of my intuition is that I can see the subtleties of life that no writer can see, I can hear the sounds of life that no writer can hear, I can create works that no writer can dream of. The tragic side of my intuition is that I sit at home ... I know when a snake moves under the ground, I feel and I forgive in my heart. That's ... bad, bad! As a result, I suffer mentally. I get nervous about why the world is like this. I wonder why people are like that. I want to get my head out of the world. So it's hard, hard for me to live in categories!"'. Perhaps, in order to create a true work of art, it is necessary, first of all, to know life and the behavior of a thousand and one people, to live side by side with those people who have different worldviews in that hectic life. This fact is unquestionably proved by the meaningful creative path and classic works of hundreds of famous writers who considered life to be the greatest school for them and lived a lifelong lesson and inspiration from it..

\footnotetext{
1 Тоғай Мурод. Бадиий мутолаа инсон кўзини очади // Ёшлик. - Тошкент: 2003. - 5-6-сонлар.
}

We are now fully aware that literature and art have always been the most important creative program for Togay Murad, who has enjoyed the life and high spirituality of this people and has reached the perfection of his creativity.

As required by the creative method, the images will be romantic and realistic. We can give the heroes of this work as examples of realistic images. The worldview and activities of realistic images correspond to real people in life. Although creative imagination is added to it, in such images the author cannot deviate from precision. Examples of such figures are Botir firqa, Rajabov, Mirzaev, Madiev, Sharof Rashidov, Obod, Dilbar.

Images are divided into specific groups according to literary type and genre, style, and visual means. In satirical images, the flaws of life are dominated by a way of poisonous laughter, ridicule. The villains are exposed to vile habits that are invisible on the outside but can be felt through our minds. "He put his hands behind his back. No belly moved forward. No, I'm going to push my belly forward ... he leaned back. No belly left in front ... Kathy went inside and disappeared. He leaned back" ${ }^{2}$. Similar facial expressions of a brave neighbor make a person laugh at himself.

A writer with a good understanding of human psychology, when depicting the mental state of the protagonist, is deeply distracted by subconscious reality and is able to convey it to the reader with great ingenuity. The following remarks of Professor Umarali Normatov, who tried to explain the state of the hero, are wellfounded. "Although the brave sect is a sect with a whole body, a man of communist faith, in the depths of his heart are hidden true

\footnotetext{
2 Тоғай Мурод. Танланган асарлар. - Тошкент: Шарқ, 2008. - Б. 206.
} 
human, national, universal, and even Islamic feelings," he said. When the time came, they came to the surface, urging him to do good deeds that contradicted the belief he had practiced in those evil times. This unique feeling in the depths of the heart is the only "key" to the salvation of this strange nature in the way out of today's whirlpool of difficult, confusing mental torture." ${ }^{\text {. Although the }}$ views of the creator and the hero are consistent, the changes in the imaginary world of the people of the transition period are also noticed by a third person critic, Professor $U$. Normatov. In the words of the poet Cholpon: "Imagination, imagination ... Imagination alone is beautiful. I am afraid of the eyes of the truth. "It is not easy to enter the world of our ancestors to create a portrait of them.

Togay Murad's heroes are really complex characters. It is impossible to give a very bad quality to an image that is capable of doing inferior things. Because the reason for the factors that make that character fall into this state seems to shine through in the plot of the work, the reader perceives it with an understanding of the cause and effect. In the speech of the brave faction, the contradictory habit of "but-but" has become a habit. This quality is also transmitted to the character of the protagonist. In his mind, the scale of religious and secular views collides. The protagonist is tormented by this torment and at the end of his life, on the verge of life and death, feels a dissatisfied mood from society.

Another important phenomenon that strikes the eye in a work of art is the system of interconnected images. Like Jamoliddin Ketmon - Aqrab - Dehqonqul - Kulmat in "Fields left by my father". In the novel "It is

\footnotetext{
${ }^{3}$ Норматов У. Нафосат гурунглари: адабийтанқидий мақолалар, эссе, хотира, қайд ва сухбатлар. - Тош-кент: Muharrir, 2010. - Б. 225.
}

impossible to die in this world", Kadyr Kul, Holmat Malay, Eson Xizmatkor, Botir Qoshchi or Zaynab Momo, Obod Mirzakhojaeva, Dilbar are systematically portrayed by their ancestors. puts. If we pay attention to the dialogue of the Botir sect with Zaynab Khotin, the author says: "- You are Mirzahojaboy's youngest weakness ... Zaynab ... Are you Zaynab's wife?

"Yes, yes."

"What's your daughter's name?"

- Obod.

- Obod, Obod ... Mirzahojaboy's daughter?

"Well, Obod ... from that man!"

"Do you know whose offspring you brought to market?" Who are you, the descendants of Mirzahojaboy?

The mother did not nail it. She stared at the ground.

The descendants of Mirzahojaboy! Said Botir firqa. - Chin, Mirzahoja-baylar did not recognize the Soviet government and fled to Afghanistan. However, he is the eldest son of Saidkhoja Eshan. In a word, eshonzoda, eshonzoda"4! In this dialogue, the confrontation between the coupler and the sect in the nature of the Brave Singer draws attention. At this point, his worldview prevails over his sectarianism. Because in his heart he had a sense of respecting the Eshans like his ancestors, of being in the service of the great knower.

Someone will bring up Mirzakhojaboy's descendants as real Soviet people. In the plot of the work, the author gives a special meaning to Mirzakhojaboy's taking his daughter to the market. The nature and behavior of Zaynab momo and her daughter Obod, who are also ashamed of the TV

\footnotetext{
4 Тоғай Мурод. Танланган асарлар. - Тошкент: Шарқ, 2008. - Б. 211.
} 
announcer, have undergone irreversible changes in their behavior. Obad Zaynab, who had taken off her veil from the face of the wind of the time or had not seen the veil on her face, could not have been a child to beautify her grandmother's heart. As a mother, Zainab was brought up not by her mother, but by the Soviet ideology, which was firmly ingrained in the minds of students in educational institutions.

In the play, the above process is vividly depicted in the spirit of the period. The main goal of the author was not to shed light on the lifestyle of Zaynab or Obad, but to give a clearer picture of the nature of Dilbar (Dilya) and others. The author's attempt to revive the original reality in the mind of the reader against the background of the Soviet-era process and to show the results and consequences of the period of reconstruction is an expression of the above ideas.

The brave faction is outraged that Dilya has taken on the appearance of a Muslim rather than the degrading deeds she did during her adolescence. "Where have you been?" Who have you been so far?

Botir firqa's hands were on his waist, his dreams were already there ...

"This woman didn't sit on any man's knees," thought Botir firqa. "She didn't sleep in the arms of any men." The protagonist laments that Dilya's language and heart are inconsistent with what she has done and is doing. The events are told to the reader through the prism of the Botir faction. If Dilbar's thoughts were also narrated, the real reality would be revealed to the reader. Was Dilbar truly repentant or hypocritical? These ideas remain open in the play. But the reader involuntarily relies on the opinion of the Botir faction, and the reader is left with a bad impression of Dilbar. The author takes the Botir faction as the leading character in the novel. In the play, the events follow in the footsteps of the protagonist. In this, other images served to create the image of the sect.

According to the leading idea of the work, the protagonists believe that their lifestyles and conditions will improve further than they hope for a happy life in the afterlife. Leaders want the people to move to practical creativity without masking religion and becoming unemployed and idle. If we focus on the life logic of the protagonists, the boundary between life and death for the literary protagonist passes through the national color. "It's not a coincidence. After all, according to the pragmatic aesthetics of modernism, the real goal of any activity is man, who must achieve the most radiant experiences in his material life. For such a subject to be active, its practical experience must include domesticmoral, religious-divine and aesthetic values. In our view, there is a shift within the protagonist of the novel towards the attainment of inner connection and spiritual integrity. In the subject, sociality and naturalness are united into a single act. Therefore, the Botir faction cannot and will not die without doing the good deeds it envisions or leaving the fate of the people in safe hands." ". Indeed, according to the author's aesthetic ideal, the character of the Botir sect is essentially a man of practice. He was given a career by that society, through which he gained a position in the political life of the society. The author adds symbolism to the episode of removing the plane trees by hashar at the end of the work. He describes the hero's psyche, his state at the time, as a

\footnotetext{
${ }^{5}$ Якубов И. Мустақиллик даври ўзбек романлари поэтикаси: Филол. фан. д-ри. ... дис. - Тошкент: 2018. - Б. 40.
} 
"man who woke up during the day" through psychological parallelism. The protagonist thinks that the incident of self-use in uprooting the plane trees he planted when he was old (condemning the nineties) is to help the system he established in those thirties to be destroyed by the rebuilders. And, mentally crushed by these events.

In some parts of the work, the author's speech, mixed with pitching, gives the impression of an open attack on the prototype of the work (it is difficult to say for sure). "Did they become worshipers? I know this. These are old alcoholics, old drug addicts. That Madiev drinks nothing but kerosene. There is no stupidity left that he did not do. Do they come and pray? Does he pray in the cafeteria again? "When he prays in the teahouse, he sees the people, Grand pather." . In this dialogue with the wife of the brave faction, a paradoxical situation is observed with regard to the protagonists of the work, which involuntarily convinces the reader.

The fact that a person's relationship with society is alienated from his nature makes it clear that he can face many tragedies. "He also emphasized the natural-biological and national-Islamic interpretations of the issue, as well as the socio-psychological aspects of the problem in explaining the essence of the problem of life and death. This made it possible to explore the inner world of the character ... At the same time, death also serves as a spiritual purification, which was presented as a way of salvation for a person who is losing his identity"7. Because of this, in

\footnotetext{
6 Тоғай Мурод. Танланган асарлар. - Тошкент: Шарқ, 2008. - Б. 206.

${ }^{7}$ Хамрокулова X. XX аср ўзбек насрида хаёт ва ўлим муаммосининг бадиий талқини. Филол. фан. д-ри. ... дис. - Тошкент: 2018. - Б. 216.
}

the protagonist's view, death seems to end relationships in a transient world. Togay Murad brutally exposes the complications of the past, leaving the protagonist in the lurch. In the worldview of the brave sect, the faith formed by the national spirit and communist notions is disputed.

The motive of the work is the creative spirit, the desire to rejuvenate the material world. The protagonist is reborn as a man of domestic-moral, religious-divine and aesthetic value. The above aspects should be taken into account in understanding and explaining the poetics of the novel.

\section{CONCLUSION}

The play focuses on some of the differences and differences in the worldviews of Botir firqa, Rajabov, Madiev and Dilbar. The writer tries to reveal the socio-political environment of the time through the views of people loyal to the Soviet ideology and "new" thinking young people in the spirit of reconstruction.

It is a good idea to look at the genealogical description of these two (Botir firqa, Dilbar) characters as keywords in the play and to connect the analysis to this basis. In the analysis of the work, we tried to find a solution to the problem posed on the basis of the author's literary-aesthetic views on the nature of the protagonists and their artistic role in the work. In fact, the play has complex images that reveal Togay Murad's grief. Examination of the work through the author's notes on the novel helped to draw clear conclusions in the analysis. 


\section{REFERENCES}

1. Qoshjonov M. Selection. Volume 2. Tashkent: 1983. - p. 154.

2. Togay Murad. Artistic reading opens the human eye // Youth. - Tashkent: 2003. Issues 5-6.

3. Togay Murad. Selected works. - Tashkent: Sharq, 2008. - p. 206.

4. Normatov U. Subtleties: literary-critical articles, essays, memoirs, notes, and interviews. - Tashkent: Muharrir, 2010. p. 225.

5. Yakubov I. Poetics of Uzbek novels of the independence period: Philol. fan. d-ri. ... dis. - Tashkent: 2018. - p. 40.

6. Togay Murad. Selected works. - Tashkent: Sharq, 2008. - p. 206.

7. Khamroqulova Kh. An artistic interpretation of the problem of life and death in twentieth-century Uzbek prose. Filol. fan. d-ri. ... dis. - Tashkent: 2018. - p. 216.

8. Quronov D. Introduction to Literary Studies. - Tashkent: People's Heritage named after Abdulla Qodiri, 2004. - 224 p.

9. Quronov D. Fundamentals of literary theory. - Tashkent: Akademnashr, 2018. $90 \mathrm{p.}$

10. Quronov D., Mamajonov Z., Sheralieva M. Dictionary of Literary Studies. - Tashkent: Akademnashr, 2010. - $300 \mathrm{p}$.

11. Quronov D. Zavqimdan bir shingil. Tashkent: Akademnashr, 2013. - 64 p.

12. Quronov D. Theoretical notes. - Tashkent: Akademnashr, 2018. - 128 p.

13. Quronov D. Poetics of Cholpon's prose. Tashkent: Sharq, 2004. 